Rev. Bras. Saúde Prod. Anim., Salvador, v.16, n.3, p.736-745 jul./set.., $2015 \quad \underline{\text { http://www.rbspa.ufba.br }}$ ISSN 15199940

\title{
Feed sorting and intake affected by the physical form and composition of the total mixed ration in dairy cows
}

\author{
Consumo e escolha do alimento afetado pela forma física e a composição de ração \\ totalmente misturada em vacas leiteiras
}
GONZÁLEZ, Félix Hilario Diaz ${ }^{1}$; OLMO, Diego Martínez Del $^{2}$; MUIÑO, Rodrigo ${ }^{3}$; BENEDITO, José Luis ${ }^{4}$; HERNÁNDEZ, Joaquín ${ }^{4}$; CASTILLO, Cristina ${ }^{4}$; PEREIRA, Víctor $^{4}$

\author{
${ }^{1}$ Universidade Federal do Rio Grande do Sul, Faculdade de Veterinária, Departamento de Patologia, Porto \\ Alegre, Rio Grande do Sul, Brasil \\ ${ }^{2}$ Nuterfeed, Aranda De Duero, Burgos, Spain. \\ ${ }^{3}$ Meira Veterinary Center, Meira, Galicia, Spain. \\ ${ }^{4}$ Universidade de Santiago de Compostela, Faculdade de Veterinária, Lugo, Galicia, Spain. \\ *Endereço para correspondência: felixgonzalez.ufrgs@gmail.com
}

\section{SUMMARY}

This study observes the effects of manipulating the diet in its physical form and in cereal composition of the concentrate on sorting behaviour, feed intake, composition of milk, and degree of discomfort in dairy cows. In a commercial dairy farm with 360 mid-lactation Holstein cows (averaged 105 days), three treatments of feeding handling were applied sequentially during 120 days, each separated by periods of 30 days of resting: (1) Time of chopping of the total mixed ration $(\mathrm{TMR})$ : $15 \mathrm{~min}(\mathrm{~N}=180)$ and $23 \mathrm{~min}(\mathrm{~N}=$ 180), (2) Physical form of the concentrate: meal $(\mathrm{N}=180)$ and pellet $(\mathrm{N}=180)$, and (3) Cereal composition in the concentrate: mix of corn, barley and wheat in traditional proportions $(3.6: 1: 1)(\mathrm{N}=$ $120)$, barley only $(\mathrm{N}=120)$ and corn only $(\mathrm{N}=$ 120). Animals feeding TMR chopped for $23 \mathrm{~min}$ selected less and consumed more ration, and had more milk protein and less discomfort than cows feeding TMR chopped for $15 \mathrm{~min}$. The physical form of the concentrate, meal or pellet, did not affect feed sorting, but the meal form resulted in greater feed intake and milk fat percentage. The type of cereal in the concentrate did not affect feed sorting but affected feed intake, milk yield and milk composition. In conclusion, it is recommended using TMR chopped during $23 \mathrm{~min}$ instead of $15 \mathrm{~min}$ and using the traditional mix of cereals in the concentrate (corn, barn and wheat) instead of using only one cereal.

Keywords: feed selection, milk composition, particle size

\section{RESUMO}

O estudo observou os efeitos da manipulação da dieta na sua forma física e na composição de cereais do concentrado sobre comportamento de escolha e consumo do alimento, composição do leite e grau de desconforto em vacas leiteiras. Em um rebanho comercial com 360 vacas de raça Holandesa no terço médio da lactação (média 105 dias em lactação), foram aplicados três tratamentos de manejo alimentar de forma sequencial durante 120 dias, separados por 30 dias de repouso: (1) Tempo de picado da ração totalmente misturada (TMR): $15 \mathrm{~min}(\mathrm{~N}=180)$ e $23 \mathrm{~min}(\mathrm{~N}=180)$, (2) Forma física do concentrado: farelo $(\mathrm{N}=180)$ e pellet $(\mathrm{N}=180)$; e (3) Composição do cereal no concentrado: mistura tradicional de milho, cevada e trigo em proporção 3,6:1:1 (N=120), apenas cevada $(\mathrm{N}=120)$ e apenas milho $(\mathrm{N}=120)$. Os animais consumindo TMR picada por $23 \mathrm{~min}$ selecionaram menos e consumiram mais ração e tiveram mais proteína láctea e menos desconforto. A forma física do concentrado, farelo ou pellet, não influenciou o comportamento de escolha da ração. $\mathrm{O}$ farelo resultou em maior consumo e maior percentual de gordura láctea. O tipo de cereal no concentrado não afetou a escolha da ração, mas afetou o consumo de alimento, a produção e a composição de leite, com maior produção e melhor conforto usando cevada. Em conclusão, recomenda-se usar TMR picada por $23 \mathrm{~min}$ ao invés de $15 \mathrm{~min}$ e usar a mistura tradicional de cereais (milho, cevada e trigo) ao invés de usar apenas um cereal.

Palavras-chave: composição do leite; escolha de alimento; tamanho da partícula 
Rev. Bras. Saúde Prod. Anim., Salvador, v.16, n.3, p.736-745 jul./set.., $2015 \quad \underline{\text { http://www.rbspa.ufba.br }}$

\section{INTRODUCTION}

Feeding costs account for over $50 \%$ of the expenses and are one of the most variable items in dairy production (IFCN, 2011). The current competitive dairy industry is pressing milk producers to take actions in order to improve productive efficiency without having additional expenses with feeding. Aspects like concentrate presentation (pellet or meal), time of grass chopping or proportion of the different cereals used in the concentrate may be managed in this respect.

The requirement of energy in high yielding dairy cows has led to an increasing intake of concentrates. Nevertheless, the ration must have appropriate quantity and quality of fibre with adequate particle size in order to prevent nutritional and metabolic disorders, like displaced abomasum, laminitis, or rumen acidosis (ZEBELI et al., 2010). In addition, a low fibre diet may lead to reduced milk fat content (GRANT et al. 1990). The NRC (2001) recommends feeding dairy cattle a minimum of $25 \%$ dietary neutral detergent fibre (NDF) to avoid milk fat depression. Besides a minimum quantity of fibre, the particle size of the forage must have adequate proportion of long and short fibres (BEAUCHEMIN et al., 2003). Consuming reduced forage particle size may lead to metabolic disorders, as cows are being fed a diet deficient in fibre. Reduced particle size cause a decrease in chewing time and thereby a decrease in rumen $\mathrm{pH}$ because less saliva is produced to buffer the rumen (JAHANI-MOGHADAM et al., 2015). In contrast, long particles compel the cows to choose the ration more carefully thus consuming less feed (BEAUCHEMIN et al. 2003).
Sorting behaviour may be defined as the selecting behaviour in favour or against of long particles that cows eat when a ration is offered. Particle size analysis may provide a useful tool to estimate sorting and thereby to improve the estimation of what dairy cows are consuming.

The aim of the present work was to evaluate the effects of different times of chopping of the ration, the form of the concentrate (pellet or meal) and the different sources of cereals on sorting behaviour, feed intake, milk yield, composition of milk, and degree of comfort in dairy cows fed totally mixed ration (TMR).

\section{MATERIAL AND METHODS}

The handling procedures in the cows of the present study agreed the rules determined by the European Council (86/609/EEC) concerning protection of animals used for scientific purposes. All animals were cared for and managed according to Spanish Government guidelines on animal care, including a forced ventilation system, well designed and managed free stalls with a comfortable sawdust surface.

The work was performed in a commercial dairy farm in Northern Spain (Province of Burgos) and 360 Holstein cows in mid-lactation (averaged 105 days) with a preceding lactation over $9,000 \mathrm{~kg}$ of milk with $3.8 \%$ of fat and $3.2 \%$ of protein were used in each study. Dairy farm was visited regularly by the clinical veterinarian, at which time a series of regular medical checks and preventive treatments were performed and recorded. Overall death frequency was $2 \%$.

Total mixed ration (TMR) was supplied once a day and on three occasions daily 
the feed was offered to each group using an appropriated vehicle. Table 1 shows the composition of the TMR offered in all treatments. An individual longitudinal feeder of $70 \mathrm{~cm}$ per animal and water of enough quantity and quality were available all the time. The ration was calculated to fulfil the nutritional requirements according to INRA (2007) for lactating dairy cattle. Samples of TMR were collected at the beginning of each stage and submitted for chemical analysis to the laboratory of the commercial feedlot farm. Analytical procedures were as follows: European Union standard methods were used for starch (Commission Directive 1999/79/EC, 1999. Official Journal of the European Communities, No. L209: 0023-0027), ether extract (Commission Directive 98/64/EC, 1998. Official Journal of the European Communities No. L257: 0014-0028) and ash (Commission Directive 81/680/EEC, 1981. Official Journal of the European Communities No. L246: 0032-0035) determinations. Both neutral detergent fibre and acid-detergent fibre were analysed according to the method of Van Soest et al. (1991). Table 2 shows the nutrients of the TMR.

Table 1. Composition of the TMR offered in all treatments

\begin{tabular}{lc}
\hline Ingredient & Dry matter basis $[\mathrm{kg}]$ \\
\hline Corn silage & 5.78 \\
Alfalfa hay & 0.92 \\
Triticale silage & 6.0 \\
Alfalfa silage & 1.04 \\
Soybean husk & 1.4 \\
Orange pulp & 0.36 \\
Concentrate* & 9.71 \\
\hline *Concentrate composition (traditional): 36.4\% corn; $24 \%$ soy; $10 \%$ barley; $10 \%$ wheat; $10 \%$ rapeseed \\
meal; $6.8 \%$ corn DDGS; $0.8 \%$ bicarbonate; $0.7 \%$ NaCl; $0.7 \%$ calcium soap; $0.3 \%$ magnesium oxide; \\
0.3\% vitamin/mineral premix (Nuter Feed, Spain). \\
In experiment 3, this traditional composition was used as a control (proportion corn:barley:wheat \\
$3.6: 1: 1$ ) and two treatments were included for comparison: only corn and only barley. In all cases, the \\
concentrate had the following nutrients (dry matter basis): crude protein 20.7\%, ether extract $4 \%$, starch \\
$31 \%$, Ca $1 \%$ and UFL $1.02 \%$.
\end{tabular}

Table 2. Nutrients of the TMR offered in all treatments

\begin{tabular}{lc}
\hline Nutrient & Dry matter basis [\%] \\
\hline Crude protein & 16.1 \\
Feed Units for Lactation (UFL) & 1.0 \\
Starch & 22.0 \\
Acid Detergent Fibre & 21.7 \\
Neutral Detergent Fibre & 26.2 \\
Ether Extract & 3.6 \\
\hline
\end{tabular}

Before applying each feeding treatments all the cows were left for adapting to the feed and environment for 30 days. Three feeding procedures were applied sequentially during 120 days, each separated by periods of 30 days of resting, selecting 360 mid-lactation Holstein cows at the beginning of each treatments of feeding handling. During the rest periods traditional feeding handling 
was applied. The treatments included: (1) Time of chopping of the TMR: $15 \mathrm{~min}$ (traditional handling in the farm, $\mathrm{N}=180)$ and $23 \mathrm{~min}(\mathrm{~N}=180)$, (2) Physical presentation of the concentrate: meal (traditional, $\mathrm{N}=180$ ) and pellet $(\mathrm{N}=180)$, and (3) Composition of the concentrate: use of different cereals: mix of corn, barley and wheat in proportion 3.6:1:1 (traditional handling, $\mathrm{N}=120)$, barley only $(\mathrm{N}=120)$ and corn only $(\mathrm{N}=120)$. The figure below illustrates the trial procedure:

\section{AP E1"Chopping time" AP E2 "Pellet vs Meal" AP E3 "Cereal source" |----30 d----|----------120 d----------|----30 d----|----------120 d----------|----30 d----|----------120 d----------| \\ * AP means Adaptation period, E1-3 means number of experiment}

The nutritional profile of the three types of concentrates was elaborated in order to reach values of nutrients (dry matter) of $20.7 \%$ of crude protein, $31 \%$ of starch, $4 \%$ of ether extract, $1.02 \%$ of Feed Units for Lactation (UFL) and $0.3 \%$ of vitamin/mineral premix (Nuter Feed, Spain) containing (per kg DM): 3,000,000 IU vitamin A; 750,000 IU vitamin $\mathrm{D} ; 12,500$ IU vitamin $\mathrm{E}$; $20,500 \mathrm{mg}$ zinc oxide; $7,500 \mathrm{mg}$ zinc chelate; $5,500 \mathrm{mg}$ copper sulphate; $750 \mathrm{mg}$ copper chelate; and $200 \mathrm{mg}$ sodium selenite.

The parameters determined were sorting of the feed, estimated feed intake, milk production, milk protein and fat content, and discomfort index. For the determination of sorting of the feed, the Penn State Particle Separator (PSPS) was used. The PSPS is a quick and costeffective method to estimate forage and TMR particle size. It is manually operated, containing a device of three sieves with pores measuring 19,8 , and $1.18 \mathrm{~mm}$ and a solid bottom pan (KONONOFF et al., 2003). The results are expressed as the percentage of particles (DM basis) retained by sieves of $19 \mathrm{~mm}$ (long fibres), $8 \mathrm{~mm}$ (medium fibres) and $1.18 \mathrm{~mm}$ (short fibres). Sorting was calculated as the intake of each particle size fraction expressed as a percentage of the predicted intake of that fraction. Samples of the TMR to be analysed by the PSPS were collected at four different points of the feeders in each batch of the treatment. The analysis was done daily at the moment of offering the feed $(0 \mathrm{~h})$ and $6 \mathrm{~h}$ after. Daily estimated feed intake was calculated by weighing the offered ration and the feed refusals (orts) before supplying new feed in each batch.

The cows were milked twice a day using automated equipment and individual milk production was registered through automatic measurement. Milk protein and fat content were determined according to the IDF (2000), using mid-infrared spectroscopy (Milkoscan FT 120, Foss Electric, Denmark).

Discomfort Index was registered at the same time everyday six hours after the supply of TMR and it was defined as the percentage of animals that were not eating, not drinking, not walking in the alley or not resting on their sawdust bedding; considering cows sitting or standing on the hallway as the uncomfortable ones.

All statistical analyses were performed using statistical package SAS System version 8 (SAS, 1999). Data were tested for normal distribution using the Kolmogorov-Smirnov test. Data of time of chopping of the TMR (15 and 23min) and physical presentation of the concentrate (meal and pellet), were compared using Student's t-test. Data of the three types of cereals in the concentrate were analysed by analysis 
of variance (ANOVA). Pairwise comparison was performed using least square means test (LSM). Significance was declared at $\mathrm{p}<0.05$.

\section{RESULTS AND DISCUSSION}

Cows feeding total mixed ration instead of separate forage and concentrate, selectively consume the various feed components in the ration. This behaviour called "sorting" is observed in dairy cows that select preferentially for the smaller grain particles in the feed and discriminate against longer forage components (De VRIES et al., 2007). This type of feeding behaviour can lead to consuming less fibre and more concentrate than expected, thereby increasing the risk of suffering subacute ruminal acidosis (COOK et al., 2004). It is recognized that feeding forage of short particle size decreases chewing activity, saliva flow, rumen $\mathrm{pH}$, inducing depressed milk fat syndrome (MAEKAWA et al., 2002) while excessive amounts of long fibres may limit intake and digestibility, affecting the energy balance of the animal (ALLEN, 1997). Increasing forage particle length led to increased intake of physically effective fibre, defined as the proportion of DM retained by 19-, 8and $1.18 \mathrm{~mm}$ sieves, which was positively associated with fibre digestion and chewing time, favouring prevention to subclinical ruminal acidosis (YANG \& BEAUCHEMIN 2006).

The effects of the time of chopping of the TMR on feed sorting, feed intake and other production parameters are shown in Table 3. Chopping the ration for $23 \mathrm{~min}$ resulted in lower proportion of the medium particles in the offered TMR $(p<0.05)$. In contrast, the proportion of short particles increased ( $p>0.05)$ compared to TMR chopped for 15 min. After 6h, longer particles decreased $\quad(\mathrm{p}<0.05)$ whereas the proportion of short particles increased $(p<0.05)$ in response to $23 \mathrm{~min}$ chopping time. The ration chopped during $23 \mathrm{~min}$ stimulated more feed intake and more milk protein than the ration chopped during less time (15min) and the cows were more comfortable as indicated by the discomfort index. The higher the discomfort index the worse the comfort condition.

TMR chopped more time (23min) than traditional husbandry (15min) increased the proportion of shorter fibres, as expected, but did not affect the proportion of long fibres in the ration offered to the animals. Nevertheless, six hours after feed delivery, the animals that were fed on $23 \mathrm{~min}$ chopped ration had consumed more long fibres and less short fibres which points to the lesser degree of sorting of feed. The animals that fed on more chopped ration also had more feed intake, a finding that contradicts other studies which recognize that feeding shorter particle size of the ration increases dry matter intake (BEAUCHEMIN et al., 1997). However, cows that have less selection of the feed are expected to eat more.

Although cows fed on $15 \mathrm{~min}$ chopped TMR had less feed intake than cows fed on 23min chopped TMR, milk yield was not affected. Particle size of forage seems not to have any effect on milk yield (BAL et al., 2000). In both groups of cows the milk fat maintained the same percentage but the milk protein percentage was higher in cows fed more chopped ration. Clark \& Armentano (1999) mentioned that milk fat is not affected by feeding rations of different silage particle size, but Grant et al. (1990) established that in forage diets different particle sizes may affect the 
milk fat and protein content. Increasing milk protein with decreased silage particle size has been observed in some studies and believed to be a result of increased starch and in essence, energy availability (BEAUCHEMIN et al., 2003). It is plausible that the behaviour of less sorting TMR in the cows eating more chopped ration lead to higher intake of total feed and, therefore, of more energy, which would be responsible for an increase of milk protein content.

Table 3. Effects of the time of chopping of the TMR on sorting of the feed and production parameters in dairy cows

\begin{tabular}{lcc}
\hline \multirow{2}{*}{ Parameter } & \multicolumn{2}{c}{ Time of chopping } \\
\cline { 2 - 3 } & $15 \min$ (traditional) & $23 \mathrm{~min}$ \\
\hline $\mathrm{N}$ & 180 & 180 \\
\hline Particle size distribution [\%] in the feed & & \\
\hline 0 h (as offered) & & $59.1 \pm 1.55$ \\
\hline Short fibre & $56.0 \pm 0.79$ & $32.8^{\mathrm{b}} \pm 0.99$ \\
Medium fibre & $35.7^{\mathrm{a}} \pm 0.73$ & $8.1 \pm 1.0$ \\
Long fibre & $8.3 \pm 0.44$ & \\
\hline 6 h after offering feed & & $60.5^{\mathrm{b}} \pm 0.45$ \\
\hline Short fibre & $56.7^{\mathrm{a}} \pm 0.88$ & $32.5 \pm 0.77$ \\
Medium fibre & $33.6 \pm 0.44$ & $7.0^{\mathrm{b}} \pm 0.57$ \\
Long fibre & $9.7^{\mathrm{a}} \pm 0.58$ & $32.84 \pm 0.99$ \\
\hline Milk yield [kg / day) & $32.59 \pm 0.99$ & $22.77^{\mathrm{b}} \pm 0.03$ \\
Estimated feed intake [kg / day] & $21.81^{\mathrm{a}} \pm 0.05$ & $3.92 \pm 0.08$ \\
Milk fat [\%] & $3.93 \pm 0.14$ & $3.3^{\mathrm{b}} \pm 0.02$ \\
Milk protein [\%] & $2.9^{\mathrm{a}} \pm 0.02$ & $4.4^{\mathrm{b}} \pm 0.46$ \\
Discomfort index* [\%] & $9.7^{\mathrm{a}} \pm 1.82$ &
\end{tabular}

Different letters in the same row indicate significant differences $(\mathrm{p}<0.05)$.

*Discomfort index: percentage of animals that were not eating, not drinking, not walking in the alley or not resting on their sawdust bedding six hours after the supply of TMR.

Cows consuming less chopped ration had a higher discomfort, maybe explained by the increased sorting behaviour compared with the cows fed on the more chopped ration.

The slightly less efficiency production ( $\mathrm{kg}$ milk yield / $\mathrm{kg}$ feed intake) of the group consuming 23min chopped TMR (1.44) compared to the group fed on the 15 min chopped TMR (1.49) would be compensated by the higher milk protein production and the better wellbeing of the cows.

Table 4 shows the effect of the physical presentation of the concentrate. The TMR containing pellet concentrate has more proportion of medium particles and less proportion of short particles than the TMR bearing meal concentrate. After $6 \mathrm{~h}$ these differences in particles size disappeared. Even though the concentrate in the meal form provoked more feed intake, this did not affect the milk yield. However, the cows that consume the concentrate in the form of meal had a higher content of milk fat and protein $(p<0.05)$ than the cows consuming pellet concentrate. The physical presentation of the concentrate apparently did not affect the discomfort index ( $>0.05)$. 
Rev. Bras. Saúde Prod. Anim., Salvador, v.16, n.3, p.736-745 jul./set.., $2015 \quad \underline{\text { http://www.rbspa.ufba.br }}$ ISSN 15199940

Table 4. Effects of the physical presentation of the concentrate in the TMR on sorting of the feed and production parameters in dairy cows

\begin{tabular}{|c|c|c|}
\hline \multirow{2}{*}{ Parameter } & \multicolumn{2}{|c|}{ Physical presentation of the concentrate } \\
\hline & Meal (traditional) & Pellet \\
\hline $\mathrm{N}$ & 180 & 180 \\
\hline \multicolumn{3}{|c|}{ Particle size distribution [\%] in the feed } \\
\hline \multicolumn{3}{|l|}{$0 \mathrm{~h}$ (as offered) } \\
\hline Short fibre & $58.1^{\mathrm{a}} \pm 1.06$ & $53.5^{\mathrm{b}} \pm 1.46$ \\
\hline Medium fibre & $30.3^{\mathrm{a}} \pm 0.76$ & $33.7^{\mathrm{b}} \pm 1.01$ \\
\hline Long fibre & $11.57 \pm 1.02$ & $12.7 \pm 1.11$ \\
\hline \multicolumn{3}{|l|}{$6 \mathrm{~h}$ after offering feed } \\
\hline Short fibre & $55.4 \pm 1.5$ & $51.8 \pm 1.5$ \\
\hline Medium fibre & $31.2 \pm 0.43$ & $33.5 \pm 1.56$ \\
\hline Long fibre & $13.4 \pm 1.25$ & $14.7 \pm 0.93$ \\
\hline Milk yield [kg / day] & $29.83 \pm 0.47$ & $29.12 \pm 0.47$ \\
\hline Estimated feed intake $[\mathrm{kg} /$ day $]$ & $22.5^{\mathrm{a}} \pm 0.33$ & $20.21^{\mathrm{b}} \pm 0.21$ \\
\hline Milk fat [\%] & $4.08^{\mathrm{a}} \pm 0.29$ & $3.34^{\mathrm{b}} \pm 0.24$ \\
\hline Milk protein [\%] & $3.26^{\mathrm{a}} \pm 0.04$ & $3.00^{\mathrm{b}} \pm 0.04$ \\
\hline Discomfort index* $[\%]$ & $10.4 \pm 1.16$ & $7.59 \pm 1.37$ \\
\hline
\end{tabular}

The concentrate in the form of meal is offered to the animals with a higher proportion of short particles and a lesser proportion of medium fibres, but the different form of the concentrate did not affect the proportion of long fibres. Six hours after offering the ration, the proportion of particles size in the feed revealed that any trend of sorting was observed as a function of the physical form of the concentrate. It is difficult to establish the ideal proportion of fibre size in the diet to obtain an effective fibre, but milk fat percentage has been used as an indicator for effective fibre, as it has proven to be an indicator of optimal rumen fermentation and ruminal $\mathrm{pH}$ levels (ARMENTANO \& PEREIRA, 1997). The pellet form of the concentrate in the present study dramatically reduced the milk fat content, suggesting that the lesser short fibres proportion offered to those animals may be a factor to be considered when choosing meal or pellet form of the concentrate, in spite of the fact that the long fibres proportion was not different between the TMRs with meal or pellet form of the concentrate. It seems likely that reducing the proportion of short fibres reduced the effective fibre, defined as the dietary fibre source that effectively stimulates rumination and salivation (MERTENS, 1997), necessary for maintaining the ruminal $\mathrm{pH}$ for an adequate proportion of acetate: propionate, which is essential for obtaining the fat precursors for the milk fat synthesis (ARMENTANO \& PEREIRA, 1997).

Table 5 presents the effects of the cereal composition of the concentrate. The concentrate with barley only as cereal component (faster ruminal degradation of starch) resulted in more milk yield and less feed intake than the other 2 treatments. This treatment also caused a better comfort in dairy cows. However, the treatment of barley had less content in milk fat and protein. The treatment of corn as the only basis of cereal 
component of the concentrate yielded the highest content in milk fat and protein. The sorting of the feed was not affected by using different cereal basis in the concentrate.

The use of different cereal grains in the concentrate as a means of having different rates of starch degradation in the rumen showed that, using barley as the single cereal in the concentrate lead to a significant increment in the milk yield with lesser feed intake, that is, improved the production efficiency. The estimate efficiency ( $\mathrm{kg}$ milk yield / $\mathrm{kg}$ feed intake) was 1.84 in the group of barley only, whilst in the other groups those values were 1.37 (corn only) and 1.43 (traditional mix of three cereals).

Table 5. Effects of the cereal composition of the concentrate on sorting of the feed and production parameters in dairy cows

\begin{tabular}{|c|c|c|c|}
\hline \multirow[b]{2}{*}{ Parameter } & \multicolumn{3}{|c|}{ Type of cereal used in the concentrate } \\
\hline & $\begin{array}{l}\text { Corn, barley and wheat } \\
\text { (traditional) }\end{array}$ & Corn & Barley \\
\hline $\mathrm{N}$ & 120 & 120 & 120 \\
\hline \multicolumn{4}{|c|}{ Particle size distribution [\%] in the feed } \\
\hline \multicolumn{4}{|l|}{$0 \mathrm{~h}$ (as offered) } \\
\hline Short fibre & $56.6 \pm 1.10$ & $58.5 \pm 1.53$ & $57.8 \pm 1.83$ \\
\hline Medium fibre & $33.9 \pm 0.78$ & $33.6 \pm 0.68$ & $33.5 \pm 1.55$ \\
\hline Long fibre & $9.4 \pm 0.59$ & $7.9 \pm 0.91$ & $8.7 \pm 0.475$ \\
\hline \multicolumn{4}{|l|}{$6 \mathrm{~h}$ after offering feed } \\
\hline Short fibre & $52.0 \pm 1.99$ & $54.2 \pm 0.52$ & $56.4 \pm 2.49$ \\
\hline Medium fibre & $35.9 \pm 1.18$ & $34.5 \pm 0.47$ & $33.9 \pm 1.43$ \\
\hline Long fibre & $12.0 \pm 1.17$ & $11.2 \pm 0.75$ & $9.6 \pm 1.27$ \\
\hline Milk yield [kg / day] & $32.29^{\mathrm{a}} \pm 0.77$ & $31.39^{b} \pm 0.74$ & $34.69^{\mathrm{a}} \pm 0.77$ \\
\hline Estimated feed intake [kg / day] & $22.5^{\mathrm{a}} \pm 0.14$ & $22.9^{\mathrm{a}} \pm 0.14$ & $18.8^{\mathrm{b}} \pm 0.14$ \\
\hline Milk fat $[\%]$ & $3.50^{\mathrm{ab}} \pm 0.24$ & $4.06^{\mathrm{a}} \pm 0.24$ & $3.22^{\mathrm{b}} \pm 0.23$ \\
\hline Milk protein [\%] & $3.22^{\mathrm{ab}} \pm 0.06$ & $3.28^{\mathrm{a}} \pm 0.06$ & $3.11^{\mathrm{b}} \pm 0.06$ \\
\hline Discomfort index $*[\%]$ & $5.85^{\mathrm{ab}} \pm 2.92$ & $10.28^{\mathrm{a}} \pm 1.06$ & $3.03^{b} \pm 1.38$ \\
\hline
\end{tabular}

Nevertheless, the lesser milk fat and protein content obtained in the group with barley may have an impact on the final results of production. The use of corn as single cereal did not bring about advantage in milk yield or feed intake compared to the traditional use of a mix of cereals (corn, barley and wheat), but produced higher milk fat and protein levels.

The use of different cereal basis in the concentrate did not have any effect on sorting of the feed, but one interesting finding was that the group fed with barley in the concentrate had a better comfort status than the other two groups.

Studies concerning the use of different cereal grains in the concentrate have proved that depending on the grain the rates of starch degradation in the rumen are different and this fact has implications on volatile fatty acids production, changes in ruminal $\mathrm{pH}$, and cellulolytic activity (LANZAS et al., 2007) which ultimately affects feed intake and milk yield. Herrera-Saldana et al. (1990) stated that barley has faster 
Rev. Bras. Saúde Prod. Anim., Salvador, v.16, n.3, p.736-745 jul./set.., $2015 \quad \underline{\text { http://www.rbspa.ufba.br }}$ ISSN 15199940

ruminal degradability than wheat, which in turn, has a faster degradability than corn. It is plausible thereby that, in the conditions of this study, using barley may have an advantage on using the mix of cereals or only corn as grain basis of the concentrate.

In conclusion, increment in milk protein production and better comfort of the cows are observed by chopping TMR during $23 \mathrm{~min}$ instead of $15 \mathrm{~min}$ without effects on milk yield. The traditional form of meal of the concentrate produces higher percentages of milk fat and protein without affecting the production efficiency. Using barley as the main cereal of the concentrate results in higher milk yield and better comfort status, but also in lesser feed intake.

\section{ACKNOWLEDGEMENTS}

The authors are grateful for the collaboration of Virginia de Pablo Sanz (ULE), the team of Nuter Feed S.A.U., LICYL (Castilla y León), the laboratory farm of Mouriscade (Pontevedra), the Pascual Agropecuario farm and doctors Teresa Castro (UCM) and Vicente Jimeno (EUITA).

\section{REFERENCES}

ALLEN, M.S. Relationships between fermentation acid production in the rumen and the requirement for physically effective fiber. Journal of Dairy Science, v.80, p.1447-1462, 1997.

ARMENTANO, L.; PEREIRA, M.

Measuring the effectiveness of fiber by animal response trials. Journal of Dairy Science, v.80, p.1416-1425, 1997.
BAL, M.A.; SHAVER, R.D.; JIROVEC, A.G.; SHINNERS, K.J.; COORS, G.

Crop processing and chop length of corn silage: Effects on intake, digestion, and milk production by dairy cows. Journal of Dairy Science, v.83, p.1264-1273, 2000.

BEAUCHEMIN, K.A.; RODE, L.M.; ELIASON, M.V. Chewing activities and milk production of dairy cows fed alfalfa as hay, silage, or dried cubes or silage.

Journal of Dairy Science, v.80, p.324333, 1997.

BEAUCHEMIN, K.A.; YANG, W.Z.; RODE, L.M. Effect of particle size of alfalfa-based dairy cow diets on chewing activity, ruminal fermentation, and milk production.. Journal of Dairy Science, v. 86, p. 630-643, 2003.

CLARK, P.W.; ARMENTANO, L.E. Influence of particle size on the effectiveness of fiber in corn silage. Journal of Dairy Science, v.82, p.581$588,1990$.

COOK, N.B.; NORDLUND, K.V.; OETZEL, G.R. Environmental influences on claw horn lesions associated with laminitis and subacute ruminal acidosis in dairy cows. Journal of Dairy Science, v.87, p.E36-E46, 2004.

De VRIES, T.J.; BEAUCHEMIN, K.A.; VON KEYSERLINGK, M.A.G. Dietary forage concentration affects the feed sorting behaviour of lactating dairy cows. Journal of Dairy Science, v.90, p.55725579, 2007.

GRANT, R.J.; COLENBRANDER, V.F.; MERTENS, D.R. Milk fat depression in dairy cows: role of silage particle size.

Journal of Dairy Science, v.73, p.18341842, 1990. 
Rev. Bras. Saúde Prod. Anim., Salvador, v.16, n.3, p.736-745 jul./set.., $2015 \quad$ http://www.rbspa.ufba.br ISSN 15199940

HERRERA-SALDANA, R.E.; HUBER, J.T.; POORE, M.H. Dry matter, crude protein, and starch degradability of five cereal grains. Journal of Dairy Science, v.73, p.2386-2393, 1990.

INTERNATIONAL FARM COMPARISON NETWORK - IFCN Dairy report. Kiel: IFCN Dairy Research Centre, 2011.

\section{INTERNATIONAL DAIRY}

FEDERATION - IDF. Determination of milk fat, protein and lactose content. Guidance on the operation of midinfrared instruments. Brussels: IDF Standard 141C, 2000.

INSTITUT NATIONAL DE LA RECHERCHE AGRONOMIQUE INRA. Feeding cattle, sheep and goats. Paris: Éditions Quae, 2007. 311p.

JAHANI-MOGHADAM, M.; MAHJOUBI, E.; HOSSEIN YAZDI, M.; CARDOSO, F.C.; DRACKLEY, J.K. Effects of alfalfa hay and its physical form (chopped versus pelleted) on performance of Holstein calves. Journal of Dairy Science, v.98, p.4055-4061, 2015.

KONONOFF, P.J.; HEINRICHS, A.J.; BUCKMASTER, D.R. Modification of the Penn State Particle Separator and the effects of moisture content on its measurements. Journal of Dairy Science, v.86, p.1858-1863, 2003.

LANZAS, C.; FOX, D.G.; PELL, A.N. Digestion kinetics of dry cereal grains. Animal Feed Science and Technology, v.136, p.265-280, 2007.

MAEKAWA, M.; BEAUCHEMIN, K.A.; CHRISTENSEN, D.A. Chewing activity, saliva production, and ruminal $\mathrm{pH}$ of primiparous and multiparous lactating dairy cows. Journal of Dairy Science, v.85, p.1176-1182, 2002.
MERTENS, D.R. Creating a system for meeting the fiber requirements of dairy cattle. Journal of Dairy Science, v.80, p.1463-1482, 1997.

NATIONAL RESEARCH COUNCIL NRC. Nutrient requeriments of dairy cattle. $7^{\text {th }}$ rev.ed. Washington, D.C., 2001.381p.

STATISTICAL ANALYSIS SYSTEM SAS. SAS/STAT user's guide. Version 8. Cary: SAS Institute inc, 1999.

VAN SOEST, P.J.; ROBERTSON, J.B.; LEWIS, B.A. Methods for dietary fiber, neutral detergent fiber, and nonstarch polysaccharides in relation to animal nutrition. Journal of Dairy Science, v.74, p.3583-3597, 1991.

YANG, W.Z.; BEAUCHEMIN, K.A. Physically effective fiber: method of determination and effects on chewing, ruminal acidosis, and digestion by dairy cows. Journal of Dairy Science, v.89, p.2618-2633, 2006.

ZEBELI, Q.; MANSMANN, D.; AMETAJ, B.N.; STEINGASS, H.; DROCHNER, W. A model to optimise the requirements of lactating dairy cows for physically effective neutral detergent fibre. Archives of Animal Nutrition, v.64, p.265-278, 2010.

Data de recebimento: $11 / 03 / 2015$

Data de aprovação: 27/08/2015 